\title{
The Luigi Gedda Institute of Medical Genetics and Twin Studies: Mount of Olives, Jerusalem Opening Ceremony-20 June 1980
} PROFESSOR GEDDA'S ADDRESS

As I look at the walls and the gates of the Old City of Jerusalem, I think, in this moment, of that passage of Psalm 147 which says: "Confortavit seras portarum tuarum, benedixit filiis tuis in te" ("For he hath made strong the bars of thy gates; he hath blessed thy children within thee"). And I would like this day, the 20 th of June of 1980, to represent a small but hopeful reason for a new blessing on Jerusalem and on its sons and daughters. For from now on and in any way that it can be useful, this Institute is at the service of this city and of those who live here.

I would like to thank the distinguished officials who have been so kind as to participate in this opening ceremony and now honor us with their presence. My special gratitude goes to Their Excellencies Msgr. Carew, Apostolic Delegate, and Msgr. Beltritti, Latin Patriarch, as well as to the Mayor of Jerusalem, Mr. Teddy Kollek. But I would like all of you to be aware that I will remember your friendship and consider your presence here today as a

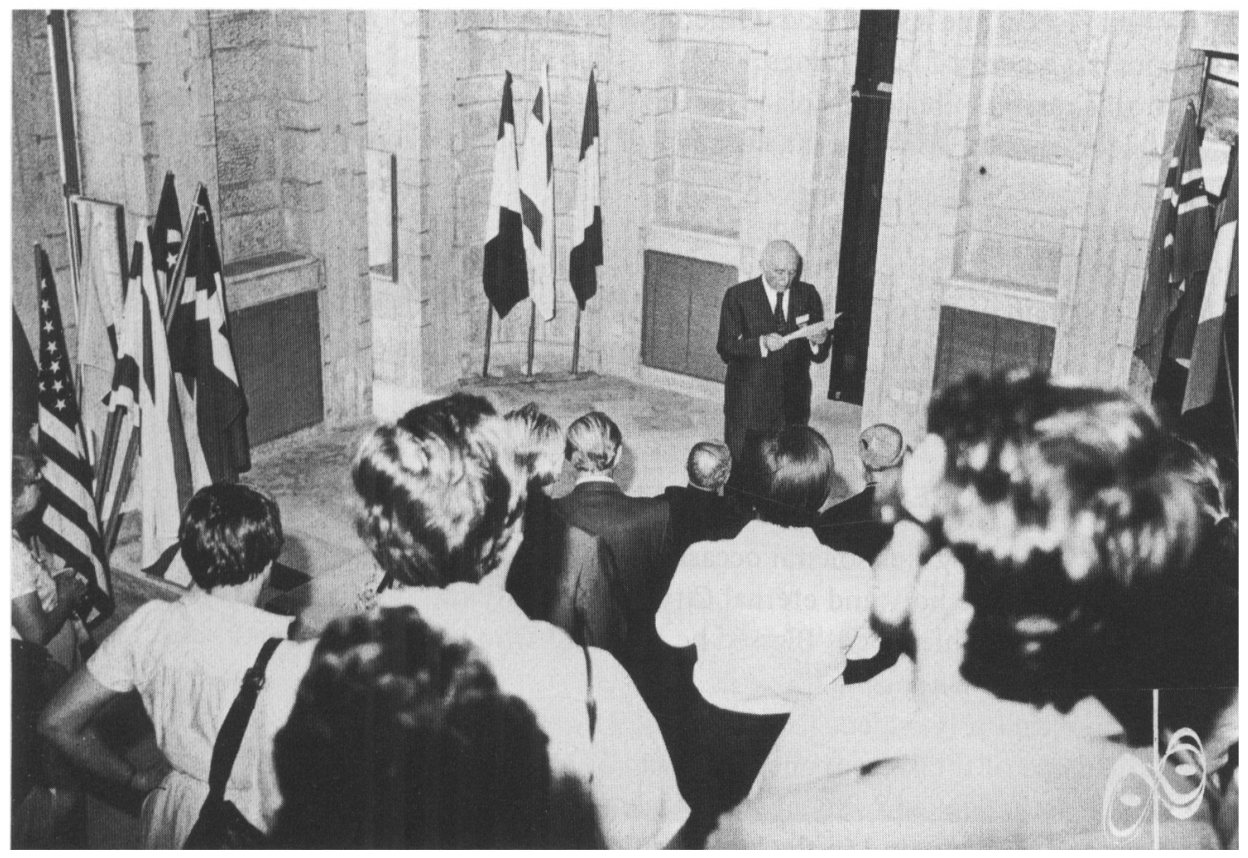


gift to my wife and to me. And I especially thank my colleagues who just took part in the Third Congress of our International Society for Twin Studies and now bring me the solidarity of the international scientific community. Only the first part of the building is completed and the Institute is not yet equipped; nevertheless, I could not lose this opportunity to open it, in the frame of our Congress and at the presence of so many famous researchers.

Today we are bringing to fruition a project conceived many years ago and started on the 28th of March 1972, when the cornerstone of the Institute was laid. The project will now proceed, both at the level of scientific research in the field of human genetics and twin studies and at the level of medical care to the general, and particularly the twin, population. This will be accomplished with the cooperation of the Brothers of the Order of Saint John of God, to whom I wish to express, through Father Eligio, Prior of the Nazareth Hospital, my deepest gratitude. The reasons for my project are basically two. The first reason, I think, is broadly shared by those who are present here today: to serve and contribute to the science of heredity, genetics, started "avant la lettre" by Gregor Mendel over 100 years ago.

Genetics has become the science of the century. Medicine, agriculture, and, broadly speaking, anthropology, have come to rely on it, because it has the capability to condition and modify the life of any species, and to affect the survival and progress, the quantity and the quality of mankind. To bring the fruits of our scientific experience into Israel thus means to pay a tribute to human genetics in this city of Jerusalem which unites three continents, Europe, Asia, and Africa.

The second reason is my own, and is shared by those who share my religious views. Modern technology is a prestigious product of the human mind, but the many results it produces have such a power and involve such a responsibility as to need to be interpreted, justified, and used, only in the frame of a religious conception.

Science in general, and genetics in particular, correspond to the Commandment of God: "Be fruitful, and multiply, and replenish the earth and subdue it." Science must therefore know and respect the law of God. Otherwise damage, and not advantage, is produced. Genetics has a need of holy things.

For this reason I chose this place, in the Kidron Valley, close to that Garden where Jesus sweat blood. Let us work so that science will not produce agony, but rather happiness and life.

The Institute is yours. It belongs to those who will need it and will share the responsibility to manage it. Let the blessing of the Father, of the Son, of the Holy Spirit, and of Mary, the Virgin of Nazareth who rose into Heaven from this Valley, descend, through the benediction that will now be given by the Patriarch of Jerusalem, Msgr. Beltritti, on this new Institute and on those who will work here.

\section{ADDRESS BY PROFESSOR ISAAC HALBRECHT (Petah Tiqva, Israel)}

It seems to me fitting this solemn occasion on this unusual spot on the historical Mount of Olives, facing the holy and eternal City of Jerushalyim, to start my words with the traditional Hebrew blessing: "Blessed be the Lord who let us survive and reach this event which we are now witnessing."

I am sure that it is evident to everybody why this Institute we are now inaugurating bears the name of the great pioneer of Twin Studies Luigi Gedda, but some people may ask why in Jerusalem and why at Gethsemani on the Mount of Olives. To me this is not less clear and perhaps am I in the best position to give you the explanation for it. 
I have been fortunate to enjoy and cherish the personal friendship of Luigi Gedda for the last two decades and during this time we have been associated in many scientific events of which the sixth World Congress on Fertility and Sterility held in Tel-Aviv in 1968 was one of the highlights. I cherish a special souvenir which Luigi Gedda gave me after the Congress: an old map of the Holy Land with the following dedication. "To my friend Isaac Halbrecht to whom I am linked by our common profound love for the Holy Land." Luigi Gedda, I have since had many occasions to listen to your explanations why this special spot on the Mount of Olives, Gethsemani, or "Gat Hashemanim" as it was called at the time of Jesus Christ, is so dear to you, my dear friend. Indeed, this spot on which the Gedda Institute stands, on the top of the Mount of Olives, is dear to all of us.

It is dear to millions of Christians in the whole world, and to Luigi Gedda, great scientist and profoundly religious man, in particular. It is dear to Jews here and in the world at large and to myself, as the place where hundreds of generations of my people have found their last and eternal rest and among them my grandparents, who have come from the Diaspora to die in Jerusalem and to be buried in the holy grounds of the Mount of Olives.

From here, you face the City of Jerushalayim, The City of Peace, and the City of David and the Prophets. From here, you can see the "Har Habait," "The Mount of the House" in the Jewish tradition, where the Holy of Holies once stood and where the Kohanim, of whom I am proud to be a descendant, worshipped the Lord and where the Levites praised the Lord singing psalms and other sacred songs.

The City of Jerusalem, so dear to all creeds, and this Garden of Gethsemani, where according to the Christian tradition the most pathetic drama of humanity has taken place, dear in particular to you my dear friend Luigi Gedda, are the best guaranty that the Luigi

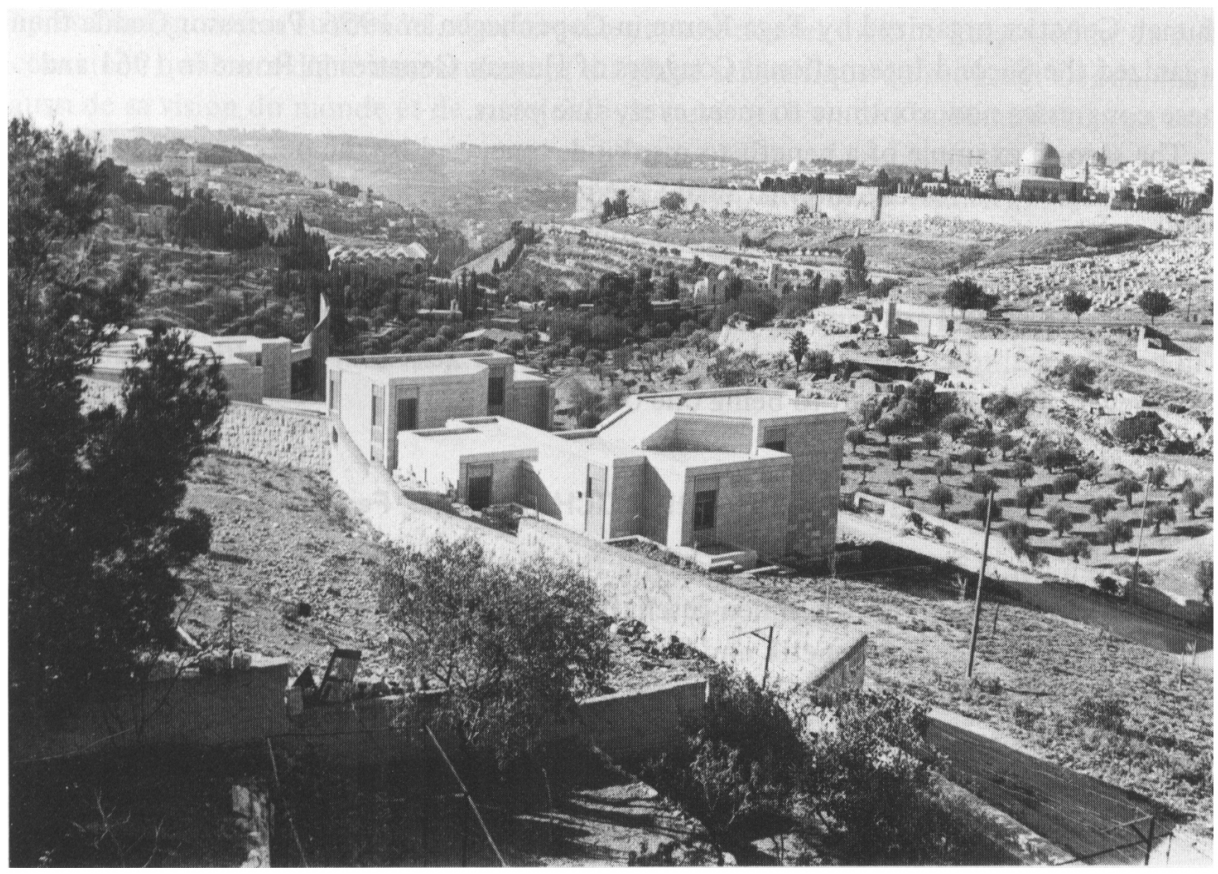


Gedda Institute will be a great center for research and study, linking together men and women of all creeds, races, and countries in the spirit of Francesco d'Assisi, il poverello, the great lover of humanity, Leonardo de Vinci, the great Italian genius and forerunner of modern science, and Gregor Mendel.

To you, my dear friend Luigi Gedda and to Signora Gedda, I wish many many enjoyable and fruitful years at the head of the Institute which bears your name. I also wish to convey to you the warmest wishes of the B. Gattegno Research Institute of Human Reproduction of the Hasharon Hospital and the Tel-Aviv University, and beg you to accept in my own behalf and in behalf of our entire staff a modest gift; all selected papers published during the 25 years of the existence of the Institute of which you have been one of the most prominent scientific advisers. Thank you.

\section{ADDRESS BY PROFESSOR H. WARNER KLOEPFER (New Orleans)}

To participate on this important historical occasion, the dedication of the Luigi Gedda Institute of Medical Genetics and Twin Studies is to me a very special honor and privilege because, 27 years ago this fall, I was present on a similar occasion, the dedication of the Gregor Mendel Institute of Medical Genetics and Twin Studies, also founded, in Rome, by Professor Gedda.

It is my wish that subsequent developments from this dedication today in Jerusalem will generate blessings for mankind that will be as important as those that already have been generated from the occasion of the dedication of the Rome Institute in 1953. Time will permit only two examples of kinds of benefits to expect.

The occasion of the dedication 27 years ago was the First International Symposium of Medical Genetics, organized in Rome by Professor Gedda in 1953. On that occasion I was with a small group of six or seven participants who thought the occasion was so good that preliminary plans were discussed which resulted in the First International Congress of Human Genetics organized by Tage Kemp in Copenhagen in 1956. Professor Gedda then organized the Second International Congress of Human Genetics in Rome in 1961 and these congresses now continue to meet every five years.

The second example of a benefit to mankind, generated by the occasion 27 years ago, were plans in 1970 for the International Congress on Twin Studies, in Rome again, in 1974. As participants in the Third International Congress on Twin Studies it is not necessary to elaborate for you the value of this example.

On this occasion I am happy to note the large participation of young investigators who will be expected to contribute to congresses during the next 27 years, although at age 67 I no longer can look forward to being one of them.

\section{ADDRESS BY PROFESSOR GERHARD KOCH (Erlangen, Federal Republic of Germany)}

1953 waren wir in Rom versammelt, um mit Ihnen, lieber Herr Professor Gedda, an der glanzvollen Eröffnung des von Ihnen geschaffenen und gegründeten "Gregor Mendel Institut für Medizinische Genetik und Zwillingsforschung" teilzunehmen.

$\mathrm{Zu}$ den damaligen Teilnehmern gehörten die weltbekannten Pioniere der Zwillingsforschung und Humangenetik: Professor Franz Kallmann aus den USA, Professor Petrus Waardenburg aus den Niederlanden, und Professor Ernst Hanhart aus der Schweiz, um nur einige zu nennen. 
Das damalige Ereignis des Jahres 1953 war ein Markstein in der Geschichte der Zwillingsforschung, die durch Ihre dynamische Persönlichkeit der Zwillingsforschung in aller Welt neue wichtige und entscheidende Impulse gegeben hat.

Heute 1980, über ein Vierteljahrhundert später, sind Zwillingsforscher aus aller Welt nach Jerusalem gekommen, um an der feierlichen Einweihung des "Luigi Gedda Institutes" teilzunehmen.

Mit diesem Institut, das nunmehr Ihren Namen tragen wird, ist Ihr Name mit goldenen Lettern nicht nur in die Geschichte der Zwillingsforschung und der Humangenetik, darüber hinaus auch in die Geschichte der Stadt Jerusalem und des Staates Israel eingetragen.

In Namen meiner hier anwesenden Kollegen aus Deutschland beglückwünsche ich Sie, lieber Herr Professor Gedda, zu diesem Institut. Wir wünschen dem Institut und seinen zukünftigen Mitarbeitern wichtige wissenschaftliche Erfolge für die Zwillingsforschung und für die Humangenetik, nicht zuletzt auch zum Wohle des Volkes von Israel.

\section{ADDRESS BY DR. ALBERT FRANCESCHETTI (Geneva)}

Je suis heureux de pouvoir vous adresser ces quelques mots en français, ceci d'autant plus que de multiples liens me rattachent à Luigi Gedda et à son oeuvre. D'abord, je viens de Genève, une autre ville internationale, siège de l'Organisation Mondiale de la Santé; puis à titre scientifique, mais surtout à titre personnel et familial.

J'aimerais rappeler ici la mémoire d'un grand ami de Luigi Gedda, je veux parler de mon père, le Professeur Adolphe Franceschetti. Ensemble avec Kallmann,. ils ont créé les Congrès de Génétique Humaine, dont le Gème aura lieu l'année prochaine ici même. Les étaient là ces géants de la Génétique Humaine à l'inauguration de l'Institut Mendel en 1953. Grâce à eux, la Génétique Humaine est devenue cette grande science que nous connaissons.

Seul, parmi ces géants de la Génétique, Luigi Gedda a pu continuer son oeuvre jusqu'à maintenant. Il nous a donné la Gémellologie, puis la Chronogénétique. Aujourd'hui, 27 ans après l'inauguration du Mendel, il nous présente son nouvel Institut Luigi Gedda. Je suis convaincu qu'il sera digne non seulement du grand scientifique qu'est Luigi Gedda, mais aussi de sa vision du monde et de sa volonté de servir au bien de l'humanité dans un esprit de paix.

Que soient nombreux, ceux qui auront le privilège de pouvoir venir ici méditer et aider à résoudre les grandes énigmes scientifiques, dans cet Institut, sur ce Mont des Oliviers, à Jérusalem, sur cette terre, dont la signification pour l'homme est grandiose et unique.

Je suis heureux d'être ici en ce moment solennel où ce joyau est remis à la communauté scientifique et internationale et je lui souhaite tout le succès qu'il mérite.

Merci, Luigi Gedda. 


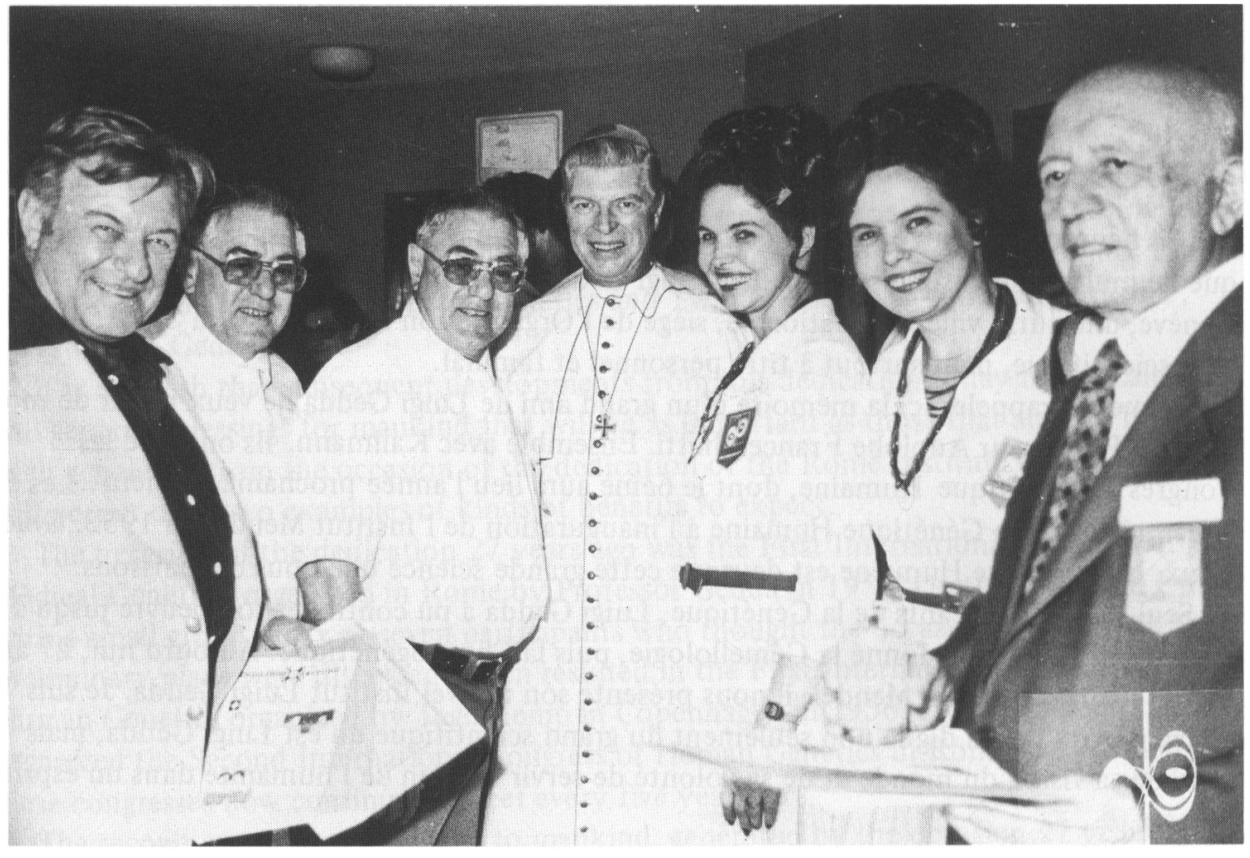

Professor Gedda, the Apostolic Delegate Msgr. Carew, and the Mayor of Jerusalem Mr. Teddy Kollek, with identical twins Lavelda and Lavona Rowe and their identical twin husbands Alwain and Arthur Richmond, at the opening ceremony of the Luigi Gedda Institute of Medical Genetics and Twin Studies in Jerusalem. 